\title{
Contagion Effect in Latin America Big Three
}

\author{
Marcos C. Holanda \\ Márcio V. Corrêa
}

Graduate School of Economics - CAEN,

Federal University of Ceará, Brazil

\section{RESUMO}

O artigo estuda a ocorrência de contágio entre as três principais economias da América Latina na segunda metade dos anos 90. O estudo baseia-se na análise do mercado de Brady Bonds do Brasil, México e Argentina. Três metodologias são aplicadas para medir o efeito contágio: correlação dos preços dos Bradies, análise do comportamento dos resíduos de regressões estimadas e extração de sinal a partir do filtro de Kalman.

\section{PALAVRAS-CHAVE}

contágio, crises financeiras, filtro de Kalman

\section{ABSTRACT}

The article investigates the occurrence of contagion among the three main economies of Latin America during the second half of the 90's. The investigation is based on the Brady Bonds market for Brazil, Mexico and Argentina. Three methodologies are applied to quantify the contagion effect: correlation of Brady Bonds price, analyses of residuals of estimated regressions and signal extraction analyses through the Kalman filter.

KEY WORDS

contagion, financial crisis, Kalman filter

JEL Classification

F34, C22 


\section{INTRODUCTION}

During the 1990's, the international financial market went through crises that placed Latin America in a way of economic instability. In response to a succession of balance of payments crises the influx of external capital to the region, that reached record levels in the first half of the decade, was strongly reduced in the second half.

In spite of balance of payments crises not being anything new in the region, two new characteristics are observed in the nineties. First, the simultaneous occurrence of crises in the balance of payments and in the banking system and, second, the strong tendency of individual crises to become general.

Investors aiming at reducing risks diversify their portfolios in the international market but information costs and market incentives make them treat different countries in a similar way, generating investment decisions of the type of domino effect or contagion effect.

The contagion can happen for several reasons, which can be divided into two main categories. The first category relates to the interdependence of markets, with the argument that the contagion is just a shock transmitted to other regions due to the high degree of economic connection among them. The second one is based on the principle that contagion represents a co-movement that is not explained by fundamentals.

The present article studies the occurrence of financial contagion between Latin America's three main economies in the second half of the nineties. The methodology used is based on the analysis of the Brady Bonds Market for Brazil, Mexico and Argentina. In this case, the evidence of contagion effect would happen if there were variations in the prices of the Bonds not explained by fundamentals.

The contagion tests are divided into three categories. The first one will be based on the analysis of correlation of the prices of the Bradies of the three countries, observing if there were increments in these coefficients in periods of crises. The second test will be based on the verification of the behavior 
of the residues of estimated regressions. The objective is to check if there were increments in the residues during the crises. The last test will be based in the use of the Kalman Filter with the objective of extracting a proxy for the contagion effect from the residues of the regressions and in this way to check its behavior in the period 1995 - 2000.

Section 1 discusses the contagion concept and section 2 presents empirical tests to identify it. In section 3 , the results of the tests performed in the present study are presented. The following section concludes the article.

\section{CONTAGION EFFECT}

The balance of payment crises of the last years, such as the Mexico crisis in 1994, the one in Asia in 1997 and, more recently, the one in Russia in 1998 and the one in Brazil in 1999 generated adverse effects on almost all of the world emerging economies.

The extent of these manifestations reached several countries, which attracted the attention of the literature in the sense of developing models to evaluate the transmission mechanisms and the economic repercussion of those crises.

Although there is not a consensus concerning the correct definition of the contagion effect, there are several attempts to characterize this phenomenon.

Kaminsky and Reinhart (1999) define contagion as the increase in the probability of occurrence of a crisis as reflection of the occurrence of a crisis in another country. In a similar way, Rigobon and Forbes (2000) consider it the propagation of shocks that can not be explained by fundamentals.

Another class of contagion definitions is related to the presence of comovements in the paths of certain macroeconomic variables of different countries. Rigobon and Forbes (2000), however, link the occurrence of co-movements to the existence of economic and financial integration, both 
in periods of crises and in periods of calms, arguing that this behavior should not be related to the contagion effect.

Although the exact causes of this phenomenon are unknown, there are some theoretical explanations for its occurrence. According to Dornbusch, Park and Claessens (2000), they can be divided into two classes: one originating from the fundamentals and the other from the investor's behavior.

In the first class, the contagion effect can arise from common shocks, commercial links and financial connections. The common shocks are characterized by the adverse effects of crises of international extents on the capital influx to the emerging countries. An increase in the United States interest rate is a good example o such a shock. In the case of commercial and financial connections, a crisis in a certain country can end up affecting the economic foundations of a second one.

In relation to the second class, the one originating from the investor's behavior, the contagion can arise from liquidity and incentives problems, caused by asymmetric information and coordination problems, from the existence of multiple equilibrium and from changes in the rules of the game.

The first class is explained like this: a crisis happened at a certain country could generate financial losses to the investor, this causes him to sell his assets from other countries to replace his net positions. This tendency to sell assets in a same period of time can also be connected to problems of incentives to the market operators.

The second class is connected to asymmetric information and coordination problems of the investors. In absence of information, a financial crisis can make the investors associate such fact to other countries, believing that they are going through similar problems. This transmission channel shows us that the investors have imperfect information about the characteristics of each country.

The third explanation for contagion effect, related to the investors' behavior, includes the existence of multiple equilibrium. In this scenario, the 
contagion arises when a crisis in a certain country causes another country to move to a new point of equilibrium, where there is a fall in the price of the assets and capital flight.

The fourth and last explanation occurs when the investors change their expectations of the rules of the game. For example, the default in Russia increased the investors' expectation that other countries could take the same action adopted by this country.

\section{TESTS OF CONTAGION}

The literature divides the tests of occurrence of contagion effect into four main groups.

Firstly, we have the contagion tests that are based on the correlation analysis between different markets. In such tests, if there are increments in the correlation coefficients during a period of crisis, then there are evidences of occurring the contagion effect.

Articles such as those of Calvo and Reinhart (1996), Valdes (1997) and Baig and Goldfajn (1998) evidenced the existence of contagion according to such methodology.

The article of Calvo and Reinhart (1996) tested the occurrence of contagion effect for some countries in Asia and Latin America, through correlation test between the returns of the Brady Bonds. The authors observed evidences of co-movements between the returns of the Bradies during the Mexico Crisis. They also confirmed that these co-movements presented distinct behaviors, suggesting that the contagion occurs more as a regional problem than as a global one.

On the other hand, Valdes (1997) and Baig and Goldfajn (1998) verified the existence of the contagion effect for some countries in Latin America during the Mexico Crisis through correlation analysis, and concluded that these shocks are basically spread through financial intermediation. 
Although this type of test is the most used in empirical works about contagion effect, there is criticism of this methodology. According to Rigobon and Forbes (1998), an increment in the correlation between markets is not itself a proof of the existence of contagion effect, since if certain markets are historically correlated, a variation in a country will naturally cause variations in the other.

A second class of tests is based on the existence of spillovers in the volatility of assets' prices.

Edwards (1998) used this methodology to verify the occurrence of contagion among Mexico, Argentina and Chile, when investigating the effects of increments in the Mexican interest rate on these two economies. Park and Song (1999) also employed this instrument to evaluate spillovers in the exchange rates of certain Asian countries during the crisis in this region. The authors concluded that a crisis in a certain country generates an increase in the probability of occurrence of crises in other countries.

A third class of tests is based on measures of the mechanisms of propagation of exogenous events, such as shocks in different countries.

The basic idea is to estimate the probability of occurrence of a crisis, dependent on the existence of crises in other countries.

An advantage of these tests is to investigate the channels of transmission of the contagion. Kaminsky and Reinhart (1998) and Baig and Goldfajn (1998) used this technique and verified increments in probability during crises.

In the article of Kaminsky and Reinhart (1998), the authors identify the occurrence of contagion through the construction of an index that sensed the fragility of the economy about to have an international crisis.

Finally, the fourth class of tests of occurrence of contagion effect is based on the analysis of influxes of capitals. 
Froot, O'Connell and Seasholes (1999) analyzed the influxes of capitals for certain countries, in the period from 1994 to 1998 and they found strong evidences of the contagion effect, arguing that the investors' actions would be an important channel of transmission of the shocks.

The present work aims at detecting the presence of the contagion effect by conducting three different tests. The first test will deal with the correlation between the prices of the Bradies. The second one is based on the analysis of the behavior of the residues of regressions estimated for the prices of them. The last test is based on the use of the Kalman Filter to extract the component of the contagion effect from these residues.

\section{EMPIRICAL RESULTS}

The basic mechanism of formation of prices of the Bradies is defined by the international parity of the interest rates:

$$
i=i^{*}+\Delta E+R P
$$

where:

i: internal interest rate;

$i^{*}$ : external interest rate;

$\Delta \mathrm{E}$ : expected exchange rate variation;

$\mathrm{RP}$ : risk premium.

Since the prices of the Bonds are specified in dollars and the exchange risk is zero we will have:

$$
\mathrm{i}=\mathrm{i}^{*}+\mathrm{RP}
$$

Following what was proposed by Erb, Harvey and Viskanta (1996), we will model the risk premium as being the combination of two risks, one economic and other financial. So, we will have: 


$$
\mathrm{RP}=\mathrm{f}(\mathrm{ER}, \mathrm{FR})
$$

where:

ER: Economic Risk;

FR: Financial Risk.

Still following what was proposed by Erb, Harvey and Viskantas (1996) and also by Edwards (1984), we will consider that the economic risk and the financial risk are a function of the following variables:

$$
\begin{gathered}
\mathrm{ER}=\mathrm{f}\left(\mathrm{D} / \mathrm{GDP}, \mathrm{RES} / \mathrm{M}, \mathrm{I} / \mathrm{GDP}, \mathrm{CA} / \mathrm{GDP}, \mathrm{PD} / \mathrm{GDP}, \Pi, \sigma_{\Pi}, \mathrm{RE}, \mathrm{OP}, \mathrm{GS}\right) \\
\mathrm{RF}=\mathrm{f}(\mathrm{RI}, \mathrm{FD})
\end{gathered}
$$

where:

D/GDP: ratio of foreign debt to GDP;

RES/M: ratio of reserves to imports;

I/GDP: ratio of investment to GDP;

CA/GDP: ratio of current account to GDP;

DP/PIB: ratio of public deficit to GDP;

$\Pi$ : inflation rate;

$\sigma_{\Pi}:$ standard deviation of inflation rate;

RE: real exchange rate;

TO: degree of trade opening;

GS: government size;

RI: real interest rate;

FO: degree of financial deepening.

Combining the equations (2) and (3) and since the variables are in logarithm form, we will have: 


$$
i_{t}=i_{t}^{*}+f(E R, F R)
$$

Assuming that $i^{*}$ is fixed and that there is an inverse relation between the assets' revenue and its price, we will get the final formulation of the econometric model to be estimated:

$$
\mathrm{P}_{\mathrm{it}}=\beta_{0 \mathrm{i}}+\beta_{1 \mathrm{i}} \mathrm{ER}_{\mathrm{it}}+\beta_{2 \mathrm{i}} \mathrm{FR}_{\mathrm{it}}+\varepsilon_{\mathrm{it}}
$$

The index $i$ represents the three countries: Argentina, Brazil and Mexico, and $\mathrm{P}_{\mathrm{t}}$ are the prices of the Par Bonds ${ }^{1}$ for the period from January 1995 to December 2000.

The equations to be estimated are:

$$
\begin{aligned}
& \log \mathrm{P}_{\mathrm{At}}=\beta_{0}+\beta_{1} \mathrm{ER}_{\mathrm{At}}+\beta_{2} \mathrm{FR}_{\mathrm{At}}+\varepsilon_{\mathrm{At}} \\
& \log \mathrm{P}_{\mathrm{Bt}}=\alpha_{0}+\alpha_{1} \mathrm{ER}_{\mathrm{Bt}}+\alpha_{2} \mathrm{FR}_{\mathrm{Bt}}+\varepsilon_{\mathrm{Bt}} \\
& \log \mathrm{P}_{\mathrm{Mt}}=\gamma_{0}+\gamma_{1} \mathrm{ER}_{\mathrm{Mt}}+\gamma_{2} \mathrm{FR}_{\mathrm{Mt}}+\varepsilon_{\mathrm{Mt}}
\end{aligned}
$$

Firstly we tested the stationarity of the series. The test adopted is the Augmented Dickey-Fuller Test (ADF).

The results (see Appendix) demonstrate the existence of stationary and non stationary series. When applying the first difference we will have the rejection of the null hypothesis of unitary root for the initially not stationary series.

The second step in the empirical treatment was to estimate the previous specified equations. We decided to adopt relations of Autoregressive Distributed Lag (ADL) type.

1 We are grateful to Prof. Marcelo Portugal for providing the series of the Par-bonds. The ParBonds are those Brady Bonds trade by their face value at the moment of debt negotiation. 
The procedure used was to go from a general model to a specific one, where we eliminated the statistically insignificant variables in the model

The results of the estimations, presented in the Tables 1, 2 and 3, demonstrate that there is no homogeneity in the parameters that explain the prices of the Bradies in the three countries.

\section{TABLE 1 - ARGENTINA}

\begin{tabular}{lrlrr}
\hline \multicolumn{4}{l}{$\begin{array}{l}\text { Dependent Variable: LGPAR } \\
\text { Sample(adjusted): 1995:03 2000:12 }\end{array}$} \\
$\begin{array}{l}\text { Included observations: } 70 \text { after adjusting endpoints } \\
\text { Variable }\end{array}$ & Coefficient & Std. Error & t-Statistic & \multicolumn{1}{l}{ Prob. } \\
\hline C & 0.292635 & 0.088321 & 3.313297 & 0.0015 \\
LGPAR(-1) & 0.829632 & 0.052326 & 15.85522 & 0.0000 \\
DLGRAR & 0.083085 & 0.035708 & 2.326780 & 0.0232 \\
DLGRIAR & -0.119837 & 0.036018 & -3.327102 & 0.0015 \\
LGGSAR(-2) & -0.100560 & 0.055103 & -1.824949 & 0.0728 \\
LGFOAR(-1) & 0.090825 & 0.044978 & 2.019332 & 0.0477 \\
LGTOAR(-1) & 0.126097 & 0.068875 & 1.830802 & 0.0719 \\
R-squared & 0.949 & Mean dependent var & 1.800 \\
Adjusted R-squared & 0.944 & S.D. dependent var & 0.067 \\
S.E. of regression & 0.015 & Akaike info criterion & -5.354 \\
Sum squared resid & 0.015 & Schwarz criterion & -5.129 \\
Log likelihood & 194.413 & F-statistic & 196.233 \\
h- Durbin & 1.749 & Prob(F-statistic) & 0.000 \\
\end{tabular}

Where:

$\operatorname{LGPAR}(-1)$ : Price of the bond with a time lag of 1 period.

DLGRAR: Variation in the ratio of reserves to imports.

DLGRISAR: Variation in the real interest rate.

LGGSAR(-2): Size of the of the Government with a time lag of 2 periods.

$\operatorname{LGFOAR}(-1)$ : degree of financial deepening with a time lag of 1 period.

LGTOAR(-1): degree of trade opening with a time lag of 1 period. 
TABLE 2 - BRAZIL

\begin{tabular}{lrlrr}
\hline \multicolumn{4}{l}{$\begin{array}{l}\text { Dependent Variable: LGPBR } \\
\text { Sample(adjusted): 1995:03 2000:12 }\end{array}$} & \multicolumn{3}{l}{} \\
\multicolumn{4}{l}{ Included observations: 70 after adjusting endpoints } \\
\hline Variable & Coefficient & Std. Error & t-Statistic & Prob. \\
\hline C & 0.136417 & 0.053015 & 2.573159 & 0.0124 \\
LGPBR(-1) & 0.911918 & 0.030258 & 30.13793 & 0.0000 \\
DLGRIBR & -0.095948 & 0.037024 & -2.591492 & 0.0118 \\
DLGREBR & -0.264202 & 0.122142 & -2.163063 & 0.0342 \\
LGISDBR(-2) & -0.009334 & 0.004999 & -1.867234 & 0.0664 \\
R-squared & 0.937 & Mean dependent var & 1.780 \\
Adjusted R-squared & 0.933 & S.D. dependent var & 0.068 \\
S.E. of regression & 0.017 & Akaike info criterion & -5.158 \\
Sum squared resid & 0.020 & Schwarz criterion & -4.997 \\
Log likelihood & 185.549 & F-statistic & 242.598 \\
h - Durbin & 0.956 & Prob(F-statistic) & 0.000 \\
\hline
\end{tabular}

Where: LGPBR(-1): Price of the bond with a time lag of 1 period. DLGRIBR: Variation in the real interest rate. DLGREBR: Variation in the real exchange rate. $\operatorname{LGSDIBR}(-2)$ : Standard deviation of the inflation rate with a time lag of 2 periods.

\section{TABLE 3 - MEXICO}

\begin{tabular}{|c|c|c|c|c|}
\hline \multicolumn{5}{|c|}{$\begin{array}{l}\text { Dependent Variable: LGPMX } \\
\text { Sample(adjusted): 1995:03 2000:12 } \\
\text { Included observations: } 70 \text { after adjusting endpoints }\end{array}$} \\
\hline Variable & Coefficient & Std. Error & t-Statistic & Prob. \\
\hline C & 0.173380 & 0.069077 & 2.509935 & 0.0146 \\
\hline LGPMX(-1) & 0.885460 & 0.035329 & 25.06338 & 0.0000 \\
\hline DLGRSMX & -0.138504 & -0.024205 & -5.722217 & 0.0000 \\
\hline LGTOMX(-1) & 0.096166 & 0.043455 & 2.212992 & 0.0305 \\
\hline LGINVMX & 0.031332 & 0.016293 & 1.923059 & 0.0589 \\
\hline DLGRMX(-2) & 0.046969 & 0.017410 & 2.697765 & 0.0089 \\
\hline R-squared & 0.961 & \multirow{4}{*}{\multicolumn{2}{|c|}{$\begin{array}{l}\text { Mean dependent var } \\
\text { S.D. dependent var } \\
\text { Akaike info criterion } \\
\text { Schwarz criterion }\end{array}$}} & 1.869 \\
\hline Adjusted R-squared & 0.958 & & & 0.060 \\
\hline S.E. of regression & 0.0121 & & & -5.878 \\
\hline Sum squared resid & 0.009 & & & -5.685 \\
\hline Log likelihood & 211.732 & \multicolumn{2}{|c|}{ F-statistic } & 322.499 \\
\hline $\mathrm{h}$ - Durbin & 0.799 & \multicolumn{2}{|c|}{ Prob(F-statistic) } & 0.000 \\
\hline
\end{tabular}

Where: LGPMX(-1): Price of the bond with a time lag of 1 period. DLGRIMX: Variation in the real interest rate. LGTOMX(-1): degree of trade opening with a time lag of 1 period. LGINVMX: Ratio of Investment to GDP - gross domestic product. DLGRMX(-2): Variation in the ratio of reserves to imports with a time lag of 2 periods. 
Analyzing the signs of the variables in the regressions, we observe that all have the expected signs. The variable real interest rate presents a negative sign for all the three estimated regressions, indicating that increments in this variable affect the credibility of the three countries analyzed negatively.

We will begin by analyzing the correlations among prices of the Brady Bonds of the 3 countries.

The strategy employed will be to recursively calculate the correlation coefficients, starting from the first 5 months and the following consecutive inclusion of each month in the 1995-2000 period. The objective is to obtain a path of the correlations along the time and to verify their behavior in the moments of crises.

Observing Figure 1 below, we can detect high correlation coefficients between Brazil - Argentina and Brazil - Mexico, even in calm periods.

It can also be observed that there was an increasing trend in the correlation coefficients for the period from January 1996 to December 1998 and a decreasing one for the following period.

Analyzing the crises in Asia (August 1997) and in Russia (August 1998), we can notice that in the first crisis there are increments in the coefficients while in the second one they changed very little.

FIGURE 1 - CORRELATION OF THE BRADIES

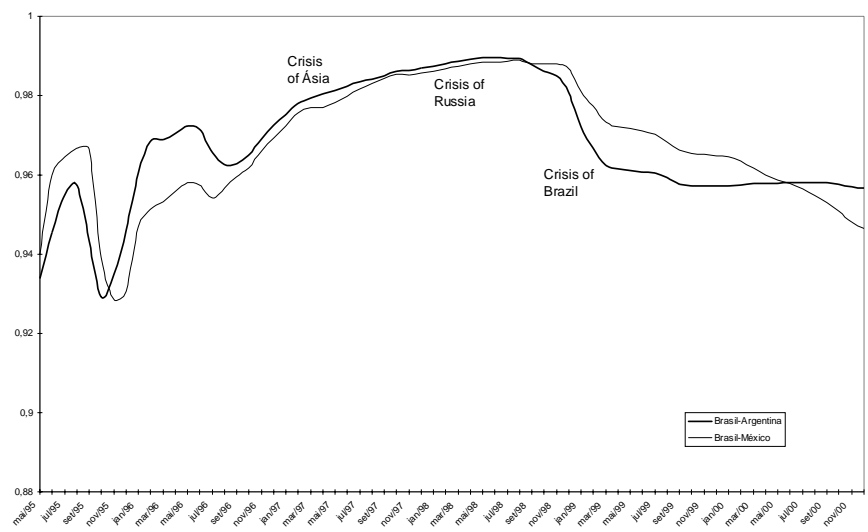


In the case of the crisis in Brazil in February 1999, we can observe a continuous trend in the fall of the Brazil-Mexico coefficient and a stability of the Brazil-Argentina coefficient. This result would indicate a process of learning of the market with reduction of the contagion effect, as well as a detachment of the Mexican economy with regard to the others.

The second technique of analysis of the contagion effect consists of verifying the behavior of the residues in the periods of crisis.

The methodology used will be based on the argument that in periods of crisis there is a reduction in the price of the Bradies which is not justified by fundamentals. Therefore, if in a period of crisis there is an increase in the residues, then there is evidence of the presence of contagion.

The empirical procedure consists of estimating the equations (8), previously defined, and saving the residues so as to analyze their behavior along the time.

\section{FIGURE 2 - EVOLUTION OF THE RESIDUES}

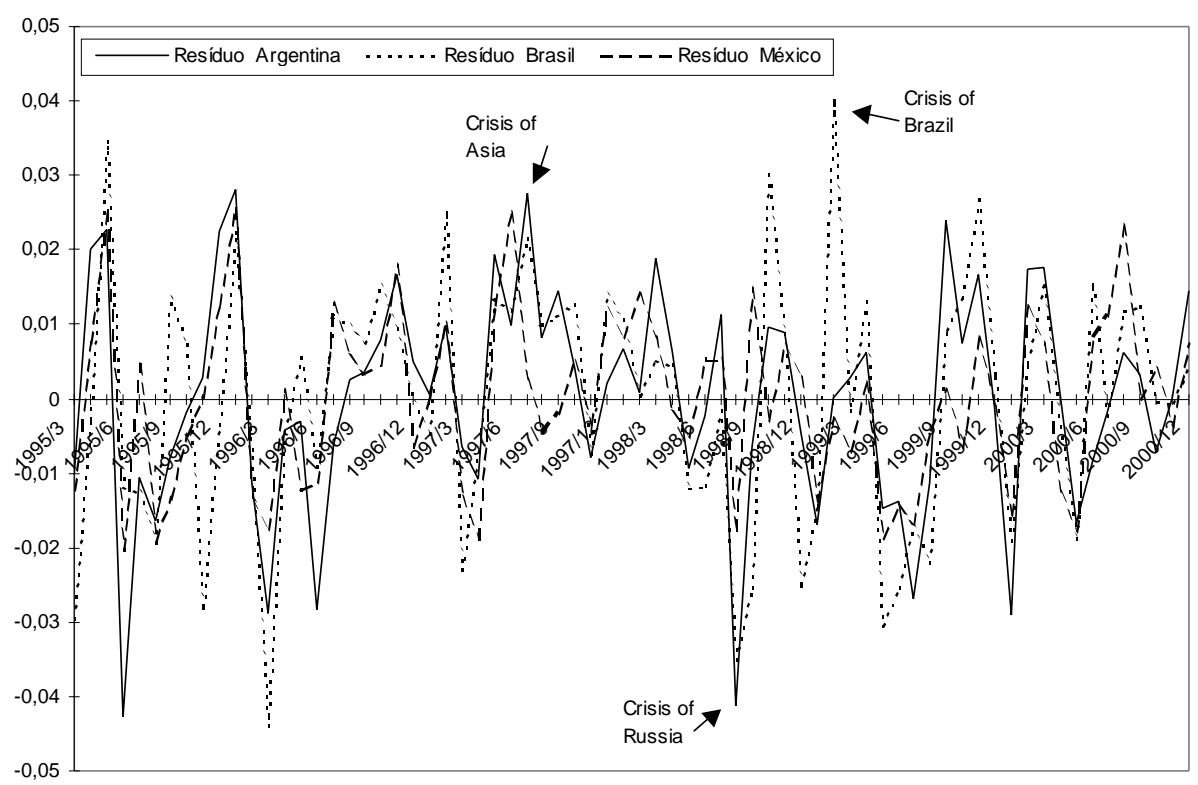


In the Asian Crisis we can observe that the country most affected was Argentina, followed by Brazil and, finally, Mexico. It must be emphasized that, during this period, there was an increment in the residues of the two South American countries while there was a fall in the residues for Mexico. The effects are similar for the case of the Crisis in Russia.

During the crisis in Brazil, the effects on Argentina and Mexico are small. For Brazil, there is a strong increase in the residue. This result suggests that the fundamentals were not able to explain the variation in the prices of the Brady of the country at that moment. The Brazilian crisis would then be best explained by second generations models of exchange rate crisis in which expectations prevail over fundamentals.

Finally, a reduction of the residues is observed in the recent period, what would be compatible with a process of reduction in the contagion effect in the region.

The third contagion test is based on the technique of sign extraction.

The methodology employed will be implemented by using the Kalman Filter to extract the contagion component from the residues of the estimated regressions. The basic idea will be to apply the algorithm developed by Kalman in order to obtain the path of the transitory component of the series of residues that is connected with the contagion effect.

The estimated equations will be:

$$
\begin{aligned}
& \mathrm{U}_{\mathrm{t}, \mathrm{i}}=\mathrm{C}_{\mathrm{t}, \mathrm{i}}+\varepsilon_{\mathrm{t}, \mathrm{i}} \\
& \mathrm{C}_{\mathrm{t}, \mathrm{i}}=\mathrm{C}_{\mathrm{t}-1, \mathrm{i}}+\omega_{\mathrm{t}, \mathrm{i}}
\end{aligned}
$$

where it is assumed that $\mathrm{w}_{\mathrm{t}}$ and $\varepsilon_{\mathrm{t}}$ are independent random variables with distribution $\omega_{t} \sim \mathrm{N}(0, \mathrm{R})$ and $\varepsilon_{\mathrm{t}} \sim \mathrm{N}(0, S), \mathrm{C}_{\mathrm{t}}$ represents the variable not directly observable of contagion which we want to estimate, and $U_{t}$ is equivalent to the residues previously estimated. 
To implement the filter we will postulate some initial hypotheses. Firstly, we will adopt the beginning period of the filter in July 1995 and that at this moment the contagion is null. Such hypothesis is based on the idea that at this time there are no evidences of the presence of the contagion effect. We will also postulate that the variance at this same moment is equal to $\mathrm{l}$ and that the contagion follows a normal distribution. Therefore, at the first instant the contagion has a normal distribution with mean 0 and variance 1 .

A second hypothesis concerns the determination of the value of S. Its value is based on what was proposed by Portugal (1996). According to that, the ratio of $\mathrm{R}$ to $\mathrm{S}$ should be small in order to obtain not very oscillatory behavior in the state variable and, since by definition the contagion is a variable that does not oscillate very much, we opted to define as being 1 and, by doing so, we keep the $\mathrm{R} / \mathrm{S}$ ratio small. So, considering the second hypothesis, the random variable $\omega_{t} \sim N(0,1)$

The third and last hypothesis relates to the value of $\mathrm{R}$. As the residues follow the same distribution of $\varepsilon_{\mathrm{t}}$, its value will be obtained directly from the series of the residues of each country.

The general results of the application of the Filter are presented in Figures 3,4 and 5 .

FIGURE 3 - CONTAGION IN ARGENTINA

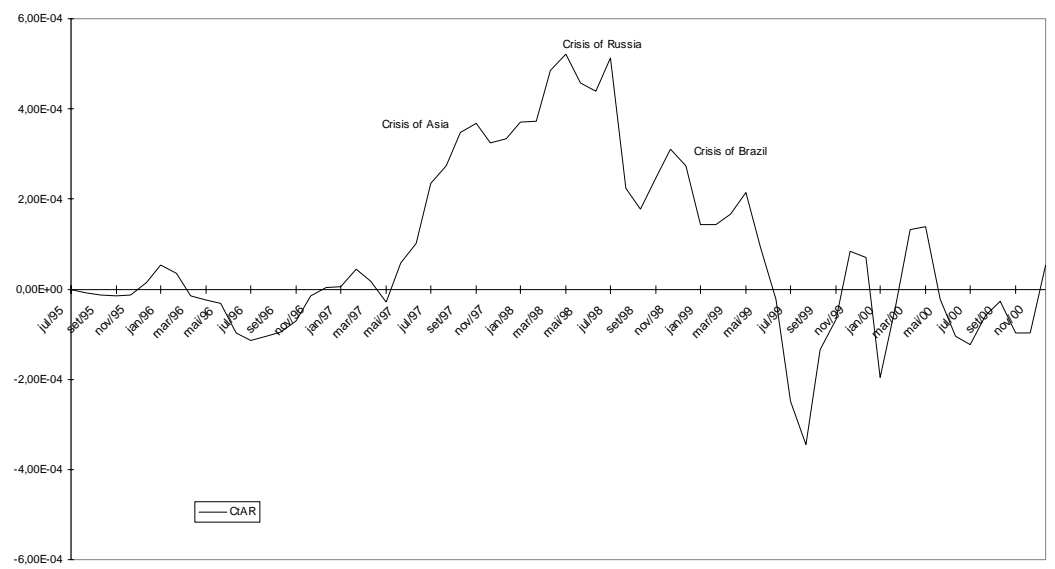




\section{FIGURE 4 - CONTAGION IN BRAZIL}

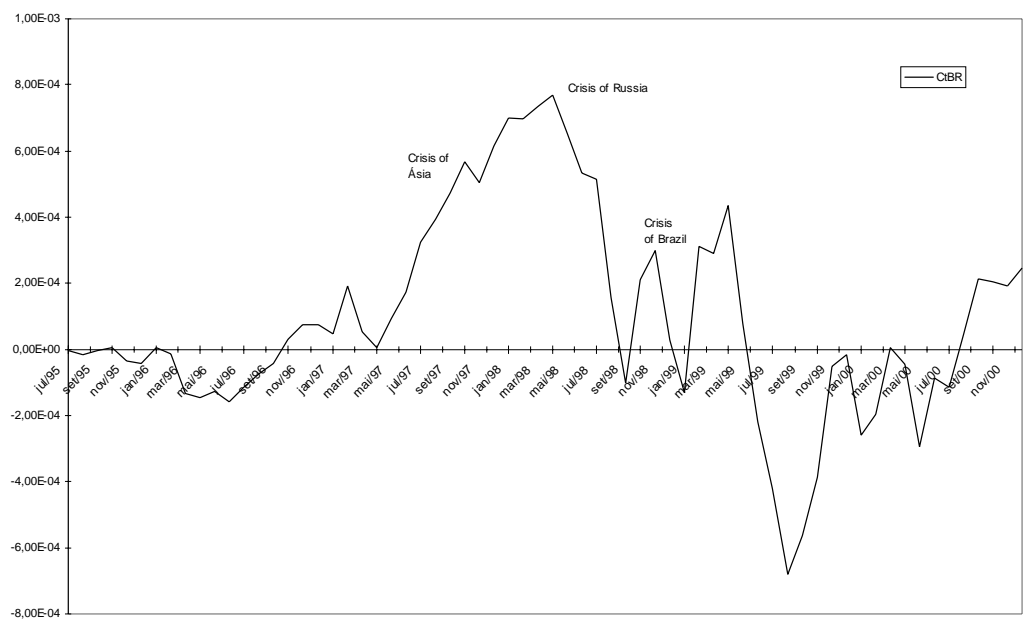

FIGURE 5 - CONTAGION IN MÉXICO

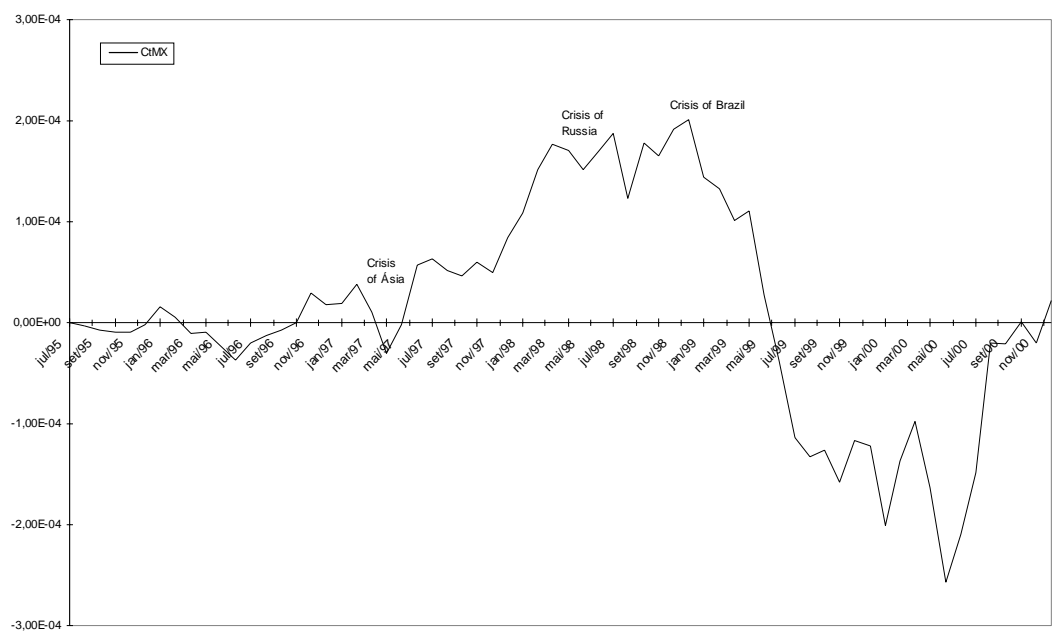

The graphs show that the contagion effect reaches a maximum during the crisis in Russia, with Argentina and Brazil having been the most affected. We can also observe that before the three crises, the value of the contagion was approximately zero. Moreover, we can also notice the repetition of the trend in reduction in the contagion in the recent period.

The case of Mexico shows that the contagion can be negative, indicating a beneficial contagion, since there is evidence of valuation, and not devaluation, of the Bradies not explained by fundamentals. 


\section{CONCLUSIONS}

Three tests were developed in this article to detect the presence of contagion effect in the three main economies of Latin America. The first test was based on the correlation analysis between the prices of the Brady Bonds. The second one was based on the analysis of the behavior of the residues of regressions estimated for the prices of the Bradies and, finally, the third test was based on the use of the Kalman Filter to extract the contagion effect component from the residues.

In the first test, an increase in the correlation coefficient would indicate signs of herd behaviour of the investors and, consequently, an indicator of the occurrence of the contagion effect.

For the second test of contagion, the methodology used was based on the argument that in periods of crisis, there is a reduction in the price of the bradies which is not justified by fundamentals. Therefore, if in a period of crisis there is an increase in the residues, then there are evidences of the presence of contagion.

The two class of test pointed for the presence of contagion in all three crises happened in the period, with the crisis in Brazil having been the least serious.

The third and last test of occurrence of the contagion effect was based on the application of the technique of sign extraction. The basic idea consisted of applying the Kalman Filter to extract the contagion component from the residues of the estimated regressions. In this case, we noticed that the Crisis in Russia was the one which caused the largest contagion effect and that there is a recent trend in reduction of such effect.

\section{REFERENCES}

AIZENMAN, Joshua. Country risk, incomplete information and taxes on international borrowing. The Economic Journal, 99, p. 147-161, 1989. 
BAIG, T.; GOLDFAJN, I. The Russian default and the contagion to Brazil. IMF Working Paper, 2000.

BANCO CENTRAL DA ARGENTINA. Disponível em: http:// www.bcra.gov.ar;

BANCO CENTRAL DO BRASIL. Disponível em: http:// www.bcb.gov.br;

BANCO CENTRAL DO MÉXICO. Disponível em: http:// www.banxico.org.mx;

BAPTISTA, Jolanda Eline Ygosse. Empirical study on LDC sopereign debt and government's credibility. Ph.D. (Tesis), Tinbergen Institute, Netherlands. Amsterdam.

CALVO, Guillermo A.; MENDOZA, Enrique G. Rational contagion and the globalization os securities markets. Journal of International Economics, 51, p. 79-113, 1998.

CALVO, S.; REINHART, C. Capital flows to Latin America: is there evidence of contagion effect? Washington, D.C.: Institute for International Economics, 1996.

CLAUDE, B. Erb; CAMPBELL, R. Harvey; TADAS, E. Viskantas. Political risk, economic risk, and financial risk. Financial Analysts Journal, v. 52, n. 6, p. 28-46, Nov/Dec. 1996.

COUNTRY REVIEW. 2001. Disponível em: http://www.country watch.com

DORNBUSCH, R.; PARK, Y. C.; CLAESSENS, S. Contagion: how it spreads and how it can be stopped. World Bank Working Paper, 2000.

EDWARDS, Sebastian. LDC foreign borrowing and default risk: an empirical investigation, 1976-80. The American Economic Review, v. 74, n. 4, 1984.

. Interest rate volatility, capital controls and contagion. NBER Working Paper 6756, 1998.

ELTON, Edwin J.; GRUBER, Martin J.; BLAKE, Christopher R. Fundamental economic variables, expected returns, and bond fund performance. The Journal of Finance, v. L, n. 4, 1995.

FORBES, Kristin; RIGOBON, Roberto. Contagion in Latin America: definitions, measurement and policy implications. NBER Working Paper 7885, 1998.

FROOT, Kenneth A.; O'CONNELL, Paul G. J.; SEASHOLES, Mark $S$. The portfolio flows of international investors. World Bank Working Paper, 1999.

FULLER, Wayne A. Introduction to statistical time series. $2^{\text {a }}$ ed. Wiley Series in Probability and Statistics, 1996. 
GOLDFAJN, Ilan; BAIG, T. Financial market contagion in the Asian crisis. Departamento de Economia - PUC/RJ, Textos para Discussão, n. 400, 1998.

HAMILTON, James D. Uncovering financial market expectations of inflation. Journal of Political Economy, 93, p. 1224-1241, 1985.

IBGE. Disponível em: http://www.ibge.gov.br/ibge.

INDEC-Ar. Instituto Nacional de Estatísticas e Censos da Argentina. Disponível em: http://www.indec.gov.ar.

IPEA - Instituto de Pesquisas Econômica Aplicada. Disponível em: http:/ /www.ipeadata.gov.br.

IZVORSKI, Igor. Brady bonds and default probabilities. IMF Working Papers, 98/16.

KAMINSKY, Graciela L.; REINHART, Carmen M. On crises, contagion, and confusion. Journal of International Economics, 51, p. 145-168, 1999.

. On crises, contagion and confusion. World Bank Working Paper, 1998.

MINISTÉRIO DA ECONOMIA DA ARGENTINA. Disponível em: http://www.mecon.gov.ar.

MINISTÉRIO DA FAZENDA DO BRASIL. Disponível em: http:// www.fazenda.gov.br.

MORAIS, Igor C.; PORTUGAL, Marcelo S. Características da volatilidade estocástica dos par bonds da América Latina. UFRGS, 1999.

. Modelagem e previsão de volatilidade determinística e estocástica para a série do Ibovespa. Estudos Econômicos, v. 29, n. 3, p. 303-341, jul/set. 1999.

PARK, Y. C.; SONG, C. Y. Financial contagion in the East Asian crises with special reference to the Republic of Korea. World Bank Working Paper, 1999.

PORTUGAL, Marcelo S. Modelos de previsão de séries de tempo. III Curso de Atualização em Economia, ANPEC, 1996.

VALDES, Rodrigo. Emerging markets contagion: evidence and theory. World Bank Working Paper, 1997.

WELCH, Greg; BISHOP, Gary. An introduction to the Kalman filter. Disponível em: http://www.cs.unc.edu/ welch/media/pdf/ kalman intro.pdf. 2001.

E-mail: holanda@ufc.br.

I am grateful to CNPq - Brazil for financial support.

(Recebido em setembro de 2002. Aceito para publicação em junho de 2003). 


\section{APPENDIX}

DICKEY - FULLER TEST

\begin{tabular}{|c|c|c|c|c|}
\hline \multirow{3}{*}{ Series } & \multicolumn{4}{|c|}{ TESTE ADF } \\
\hline & \multicolumn{2}{|c|}{ Test } & \multicolumn{2}{|c|}{ Critical Values } \\
\hline & & & $5 \%$ & $10 \%$ \\
\hline \multicolumn{5}{|l|}{ Bond Price } \\
\hline Argentina & Level & -3.83 & -2.90 & -2.58 \\
\hline Brazil & Level & -3.48 & -2.90 & -2.58 \\
\hline Mexico & Level & -3.59 & -3.47 & -3.16 \\
\hline \multicolumn{5}{|l|}{ Debt/GDP } \\
\hline Argentina & $1^{\text {st difference }}$ & -5.20 & -1.94 & -1.61 \\
\hline Brazil & $1^{\text {st difference }}$ & -4.75 & -1.94 & -1.61 \\
\hline Mexico & $1^{\text {st }}$ difference & -4.68 & -1.94 & -1.61 \\
\hline \multicolumn{5}{|c|}{ Reserves/Imports } \\
\hline Argentina & $1^{\text {st difference }}$ & -4.53 & -1.94 & -1.61 \\
\hline Brazil & $1^{\text {st difference }}$ & -5.72 & -1.94 & -1.61 \\
\hline Mexico & 1st difference & -4.73 & -1.94 & -1.61 \\
\hline \multicolumn{5}{|c|}{ Investment/GDP } \\
\hline Argentina & Level & -4.64 & -3.47 & -3.16 \\
\hline Brazil & Level & -4.67 & -3.47 & -3.16 \\
\hline Mexico & Level & -5.53 & -2.90 & -2.58 \\
\hline \multicolumn{5}{|l|}{ Inflation Rate } \\
\hline Argentina & Level & -6.61 & -3.47 & -3.16 \\
\hline Brazil & Level & -4.40 & -3.47 & -3.16 \\
\hline Mexico & Level & -3.20 & -2.90 & -2.58 \\
\hline \multicolumn{5}{|c|}{ Standard Deviation of inflation rate } \\
\hline Argentina & Level & -5.13 & -2.90 & -2.58 \\
\hline Brazil & Level & -6.30 & -2.90 & -2.58 \\
\hline Mexico & Level & -4.00 & -3.47 & -3.16 \\
\hline \multicolumn{5}{|c|}{ Real exchange rate } \\
\hline Argentina & $1^{\text {st difference }}$ & 3.63 & -1.94 & -1.61 \\
\hline Brazil & 1st difference & -4.11 & -1.94 & -1.61 \\
\hline Mexico & $1^{\text {st difference }}$ & -4.09 & -3.47 & -3.16 \\
\hline \multicolumn{5}{|c|}{ Degree of trade opening } \\
\hline Argentina & Level & -5.62 & -1.94 & -1.61 \\
\hline Brazil & Level & -2.60 & -2.90 & -2.58 \\
\hline Mexico & Level & -6.04 & -2.90 & -2.58 \\
\hline \multicolumn{5}{|c|}{ Government size } \\
\hline Argentina & Level & -6.12 & -3.47 & -3.16 \\
\hline Brazil & Level & -5.15 & -1.94 & -1.61 \\
\hline Mexico & Level & -4.08 & -3.47 & -3.16 \\
\hline \multicolumn{5}{|c|}{ Real interest rate } \\
\hline Argentina & $1^{\text {st difference }}$ & -4.50 & -2.90 & -2.58 \\
\hline Brazil & $1^{\text {st }}$ difference & -4.74 & -1.94 & -1.61 \\
\hline Mexico & $1^{\text {st }}$ difference & -5.30 & -1.94 & -1.61 \\
\hline \multicolumn{5}{|c|}{ Degree of financial deepening } \\
\hline Argentina & Level & -3.59 & -3.47 & -3.16 \\
\hline Brazil & Level & -3.15 & -2.90 & -2.58 \\
\hline Mexico & Level & -5.23 & -2.90 & -2.58 \\
\hline
\end{tabular}

